\title{
MAKING A NEW CONSENSUAL ELITE IN SERBIA
}

\author{
MLADEN LAZICl - JELENA PESIC
}

\begin{abstract}
The text firstly addresses the thesis that systemic transformationfrom a socialist to a capitalist order - changes both the preconditions on the basis of which political elite is constituted, and its main characteristics. Considering the specific course of transformation in Serbia, this indicates the difficulties for the transformation of its divided political elite - characterizing the aftermath of the breakdown of socialism - into a consensual elite that represents a type prevailing in liberal-democratic systems. The political elite in Serbia may thus be defined as primarily fragmented, with initial elements of consensuality. The main thesis is examined through an analysis of the changes in the character of political elites at two different levels: subjective, regarding their attitudes towards the EU based on 2007 and 2009 IntUne data; and objective (patterns of recruitment of their members based on 1989, 2003 and 2015 data on intra - and intergenerational mobility). The main findings reveal the gradual (although not yet completed) consolidation of political elites regarding their attitudes towards the EU, but also changing patterns of elite members' recruitment based on political competition and the increasing self-reproduction of the ruling elites, indicating the formation of biased pluralism.
\end{abstract}

KEYWORDS: elite consent, recruitment, attachment to the EU

\section{INTRODUCTION}

The collapse of socialism marked the beginning of a process of social transformation that involved a change in the entire mode of reproduction of social life. This process, which implied the creation of institutional and actor assumptions about the constitution of a society based on market economy

\footnotetext{
1 Authors are affiliated to the Faculty of Philosophy, University of Belgrade, e-mails: mlazic@f.bg.ac.rs; jlpesic@f.bg.ac.rs
} 
and liberal democracy, also marked a change in the way in which dominant social relations, including class relations, were constituted, as well as in the mechanisms of the reproduction of basic social groups. Social conditions on the basis of which dominant social group under socialism - nomenklatura - had been reproduced thus were abandoned, while the new conditions needed time to stabilize and to become a solid basis for the reproduction of the new dominant social groups. In most Central and Eastern European societies, transformation processes towards free market economy and liberal democracy were directed either by the new (political) elites that emerged after the collapse of socialism, or by the reformed old elites. The whole process lasted about a decade and a half, being completed with the accession to the European Union in the first decade of the twenty-first century. However, in Western Balkan societies, and in Serbia in particular, the processes of post-socialist transformation took a specific path, marked by involvement in civil wars and by international isolation. We can roughly distinguish two phases of this process: a period of 'blocked' transformation when the systemic changes were directed almost exclusively by ex-nomenklatura members, organized through the Socialist Party of Serbia (SPS); and a period of 'unblocked' transformation, during which the majority of institutional reforms towards a liberal capitalist mode of social reproduction were implemented by the new political elites who periodically changed their ruling positions. This second phase was marked not only by an acceleration of systemic changes, but also by the gradual start of the accession negotiations with the European Union. Given the fact that the accession process is not yet complete, the issue of EU integration still represents one of the major problems Serbian political elites are facing (particularly after the institutional crisis of the EU, which made Serbia's accession, as well as institutional reforms, even more uncertain).

In this text we test our thesis about the gradual formation of the consensual type of political elite in Serbia, and the corresponding type of political order consolidated democracy (Higley - Lengyel, 2000) - through an analysis of the changes in the objective and subjective characteristics of this group. Objective traits of the political elite will be analyzed through changes in recruitment mechanisms and the patterns of reproduction of this group, while subjective characteristics are examined through attitudinal changes towards the European Union. 


\section{SPECIFICITIES OF PLURALIST POLITICAL TRANSFORMATION IN SERBIA}

The limitations of this text do not allow for us to provide detailed insight into the recent history of the pluralist - parliamentary - political system in Serbia. ${ }^{2}$ Suffice to recall that the initial conditions for the constitution of the new political subsystem were defined by the top ranks of the hitherto socialist nomenklatura to its own advantage. The majoritarian electoral law enabled an overwhelming prevalence in the new parliamentary political elite of its former members, far in excess of voter support (the Socialist Party of Serbia/SPS won almost $80 \%$ of seats based on less than $50 \%$ of electoral votes; Jovanović 1997). This structure of power further resulted in the retention of elite political positions by members of this group in other state apparatuses.

A review of the initially unsuccessful process of the constitution of political pluralism in Serbia in the early 1990s (from the point of view of liberal principles) should not disregard the following fact: although the previously ruling group retained control over the organizational resources of the state, as mentioned above, the new institutional order itself created the preconditions for radical change. The legalization of party pluralism, the existence of alternative political options advocating the interests of different old and newly emerging social groups (private-owner economic elite, as well as medium and small entrepreneurial strata), and the dramatic economic and political crisis against the background of wars and international isolation - all were conditions that increased the possibilities for radical change in the existing composition and mode of reproduction of the new political elite.

The first important changes of this kind ensued from the local elections near the end of 1996, when governance in all major cities in Serbia, and especially Belgrade, was taken over by leaderships of the until-then opposition parties. An even more radical change occurred after the presidential and parliamentary elections in the autumn of 2000, when opposition parties also assumed control over the entirety of state apparatuses. In this context, the fact that the elections in both cases required the support of mass protest movements of the population to secure the recognition of electoral results is of lesser importance than the reality that the combination of institutional and extra-institutional means finally ensured the practical prevalence of the new recruitment form of the political elite. This was accompanied by a substantial breakthrough of new members of this elite into state apparatuses. Also crucial was the fact that the turnabout of 2000

2 See, inter alia: Goati et al. 2002, 2006; Lutovac ed. 2006; Slavujević 2007; Vukomanović 2010; Stojiljković 2015; Jovanović - Radović - Marković 2016. 
created the conditions for the gradual reinforcement and stabilization of this stratum's new mode of reproduction. Thus all subsequent elections essentially observed the liberal pluralist principles of relatively fair political competition and relinquishment of control over state apparatuses to electoral winners.

A decade-long blocking of system transformation in Serbia, especially during a situation of civil wars and international isolation, had lasting and important consequences for the formation of the political subsystem. Any analysis of the way in which political relations were formed can benefit from the typology of political elites developed and applied by Higley in his study of these changes (see Higley - Lengyel, 2000: 1-21). ${ }^{3}$ According to this author, two criteria internal differentiation and unity of the group - enable distinction between four types of political elites: consensual, fragmented, ideocratic, and divided. Their characteristics are defined in the following manner:

Typical of consensual elites is their acceptance of the ethos of unity despite existing differences, self-restraint in advocating specific interests, and an inclination towards compromise, as well as firm interconnection of their factions. These are the elites which operate in consolidated (liberal) democracies.

Fragmented elites lack a common ethos, or have a poorly developed one, and are characterized by mutual suspicion and distrust. Their factions are internally firmly interconnected, but their mutual links are poorly developed. They are typical of unconsolidated democracies.

Ideocratic elites have a united system of beliefs and their internal bonding is ensured by a powerfully centralized political party or movement. They are characteristic of totalitarian or post-totalitarian regimes.

Finally, divided elites are based on deeply conflicted beliefs, and their interconnection is reduced exclusively to networks within individual factions, one of which is dominant. They are common in authoritarian and sultanistic regimes (Higley - Lengyel, eds. 2000: 7).

Within the conceptual frameworks so defined, changes in the Serbian political subsystem developed in the following manner. Instead of the previous, socialist, ruling 'ideocratic' elite (ideologically and organizationally firmly centralized nomenklatura), during the first 'blocked' period of systemic transformation, an elite was formed with dual characteristics. Viewed as a whole it was constituted as a 'divided elite' composed in ideological terms of hostile and confrontational groups: the 'forces of the old regime' and 'democratic forces'. Moreover, during the 1990s, the former group, the nomenklatura successor, with the ample use of

\footnotetext{
3 We should note that Higley analyses political elites as essentially autonomous social groups, while they are here viewed as part of a single emerging capitalist ruling class in relation to other basic social groups. See also, Higley - Burton 2006.
} 
non-liberal means - the normative pluralist order notwithstanding - continuously sustained its dominant position (leadership of the SPS and its satellite parties). On the other hand, parties of the 'democratic opposition' were constituted as a mutually conflicted 'fragmented elite', parts of which were internally firmly linked, just as the group in power, by the existence of an indisputable leader.

An explanation of this course of changes in Serbia should take into account the following facts. As already mentioned, the initial conditions for the establishment of political pluralism (majoritarian electoral law) enabled the party whose leadership held power during socialism - SPS - to secure a remarkably convincing electoral victory at the first multiparty elections in 1991. It thus replaced its political monopoly with unquestionable domination, now 'democratically' legitimized by formally pluralist elections. Furthermore, since at the time of war the defense of the national interest was made central to political competition by almost all political actors of any importance (except for the Association for the Yugoslav Democratic Initiative, and the Alliance of Reform Forces of Yugoslavia), it was fairly easy to present electoral rivals as national traitors, which in the long run led to the labelling of political opponents as enemies of the state. This situation provided the basis for the constitution of a divided political elite with deeply opposed worldviews, and the efforts of each of the groups to gain exclusive political domination and, if possible, completely eliminate their political rival. On the other hand, the unexpected defeat of the democratic parties at the first election gave rise to lasting and irreconcilable conflicts among them. They blamed one another for the initial and every subsequent electoral defeat, such overall divisiveness being a specific characteristic of elite fragmentation.

The electoral defeat of the SPS in 2000 started the process of the abolition of the dual nature of the political elite in Serbia. Typical traits of the divided elite gradually weakened, to the extent that the SPS abandoned 'ideocratic' pretensions and accepted the pluralist rules of the game. On the other hand, antagonisms between the parties of the hitherto democratic opposition did not decrease, thus creating a political elite characterized by fragmentation, reinforced by the distrust of the pluralist transformation of SPS and the continuing overtly undemocratic declarations of the Serbian Radical Party/SRS. ${ }^{4}$ This furthermore means that the tendencies of the Serbian political elites' drawing nearer to the consensual form, as the necessary preconditions not only for the liberal-

4 SRS won the largest number of votes at parliamentary elections in $2003(27.61 \%)$, and then continuously increased its number of supporters in subsequent elections $(2007: 28.60 \% ; 2008$ : $29.46 \%$ ), only to 'cede' its primacy to the splinter Serbian Progressive Party/SNS which won $24.4 \%$ of the vote at 2012 elections (with $4.61 \%$ of the SRS votes). 
democratic consolidation of the political order, but also for consolidation of the whole capitalist class in Serbia, were substantially slowed down.

Political changes in 2000 are also directly linked with the reinforcement of the position of society's economically dominant group, the new economic elite. The interests of this group were represented not only by the former opposition parties which had then taken power, but increasingly became the orientation of a substantial part of the SPS (a party which - more in ideological terms than that of personnel - 'reconstructed' itself after the extradition of its hitherto leader Milošević to The Hague Tribunal). This established another basis for the weakening of Serbian political elite characteristics that is typical of the divided type, and for its transformation into the fragmented type (of all parliamentary parties, only the SRS stuck to the old principles of the complete exclusion of political adversaries). The transition itself, however, contained important ambivalent elements. The fact that the SPS (as well as the SRS) was not lustrated and removed from the political struggle due to the nondemocratic nature of its rule suggested the orientation of the new power towards building the relations typical of the consensual elite. On the other hand, uncertainty concerning the conduct of representatives of the old regime should they again come to power, as well as the mutual relations of parties with already liberal-democratic orientations, indicated that the fragmented nature of the political elite would not be easily overcome.

Finally, we may say that during the past fifteen or so years - since the principle of the periodic change of power-holders started to take firmer hold with the approximately equal competitive chances of all pretenders, the reversals of electoral victors and the peaceful yielding of positions by their previous holders - the political process still displayed some ambivalent features. In the country a liberal-democratic order has been institutionally established, wherein parliamentary, executive and judicial powers are separate, where elections are held according to the rules in four year intervals (or more often) with their results being recognized by the losing parties (which means that the organization of elections themselves is relatively fair) and whereby minority rights are protected, at least in principle. On the other hand, the significant participation of the public sector in the economy provides the state with large economic resources that are often used in a manner characteristic of 'political capitalism' (appointment of party cadres to the management of public enterprises; employment of party members in state apparatuses as well as in public companies; use of these companies' funds for party promotion - 'rewarding' media that favor certain political parties by means of paid adverts etc.). In addition, repressive state apparatuses are used for party purposes (police and judicial prosecution of oppositional party officials is still no rarity, although the legal foundation of 
such is often unconvincing, as reflected in the small number of effective court rulings). Attacks on political opponents - most often in the so-called yellow press, under party control or influence - as a rule include references to drastic moral degradation, etc. Therefore, ascendance to power in Serbia also generates political-economic 'extra profit' (and electoral defeat a commensurate 'extra loss') in the form of economic benefits, as well as increases the chances of prolonged rule. With the undeveloped democratic political culture of both the political elite and the general population due to the absence of a democratic tradition, these 'extra' gains/losses act as a powerful factor, sustaining the fragmented nature of the political elite in Serbia.

The thesis on the changing character of the political elite in Serbia during the period of post-socialist transformation will be tested using two different dimensions: subjective and objective. The subjective dimension refers to attitudinal changes of the members of political elite. Since one of the biggest challenges the Serbian political elite is faced with is accession to the EU and the processes of EU integration, we will examine whether changes in their level of attachment to the EU and trust in European institutions indicate the process of formation of a consensual type of elite and a correspondingly liberaldemocratic type of political system. The second dimension that allows us to test the thesis refers to objective changes in the recruitment patterns and patterns of self-reproduction of political elite members. Namely, while under socialism, the appointment of nomenklatura members represented the main mechanism of elite recruitment, while in consolidated democratic and pluralist political systems competition of the political parties in free and fair elections represents a major channel for individual ascendancy to political power positions. Changes in recruitment patterns and in mechanisms of the self-reproduction of political elites thus will show whether the political system in Serbia underwent the necessary transformation to meet the criteria for a consolidated democratic order.

\section{THE SERBIAN POLITICAL ELITE AND THE EU}

In trying to describe the processes of postsocialist transformation (and the transformation of the political elite in Serbia) in relation to the European Union and EU integration, we can distinguish three different phases that roughly coincide with changes in the overall character of the Serbian political system and of the political elite according to the criteria provided by Higley - Lengyel (2000). 
During the first phase that lasted from the break-up of the Yugoslav state until the 2000 turnover (the phase of 'blocked transformation'), the political elite in power - former nomenklatura members organized in SPS - operated a policy of isolationism towards the EU that was adopted at the time of UN sanctions against Serbia and reached its peak during the NATO bombing in 1999. The opposition elite, on the other hand, used pro-European rhetoric to mobilize the population, promising to bring to Serbia the process of EU accession as soon as they came to power (Lazić - Vuletić, 2009: 989). In other words, the question of EU accession represented one of the major ideological cleavages between opposing, hostilely confronted (i.e. 'divided') political elites.

The second phase started after the elite turnover in the year 2000, when exopposition, pro-EU parties came to power, and roughly lasted until the year 2012 (when SNS won the elections). Although the ruling elite adopted a policy of opening towards EU integration, anti-EU parties that were once part of the Milošević regime remained influential (enjoying the support of a significant part of the population, due to the unresolved territorial issues concerning the former Serbian province of Kosovo that nurtured nationalist attitudes). Whilst ideological cleavages concerning EU accession still remained, the increasing political strength of pro-EU parties based on the idea that EU membership represented the vitally important long-term political and economic interests of the country (Lazić - Vuletić, 2009: 990) contributed to shaping of the character of the elite as 'fragmented'. Empirical data ${ }^{5}$ on the level of attachment to the EU of the political elite members ${ }^{6}$ in a comparative context underlines the 'fragmented' nature of the Serbian political elite during this period. Namely, IntUne data show that the Serbian political elite displayed one of the lowest levels of EU-attachment scores (together with Great Britain) among the examined European political elites (note: Serbia was the only non-EU country included in the surveys). Although these scores were in both years (2007 and 2009) still above the theoretical means, implying overall dominant support for EU integration, a significant drop in EU attachment was recorded in 2009 among the Serbian political elite, placing it at the bottom of the scale (Graph 1). Having in mind the fact that the ex-opposition parties that came to power in year 2000 promised relatively fast access to the EU, and the fact that not only did this not happen but also that the future prospects of EU accession were very much uncertain, a decline in EU attachment seemed to be unavoidable, even among pro-EU elites. Looking at IntUne 2009 Serbian data, the fragmented

\footnotetext{
5 Gathered through the IntUne project in 2007 and 2009 in 17 European countries. For more on this, see: https://dbk.gesis.org/dbksearch/sdesc2.asp?no=5696\&db=e\&doi=10.4232/1.11649

6 Measured on a 4-point scale, ranging from 'lack of attachment' to 'very high attachment'.
} 
nature of the elite is immediately obvious: stronger EU attachment is recorded among government parties (2.94) than among opposition parties (2.21), while in ideological terms the highest level of attachment is recorded among representatives of socialist/social democrat parties (3.04) and those representing ethnic minorities (3.00), while the lowest level of attachment is displayed by left liberals (2.00) and conservatives (2.20) who score below the theoretical mean.

Figure 1 Mean scores of EU attachment by country (2007 and 2009)7

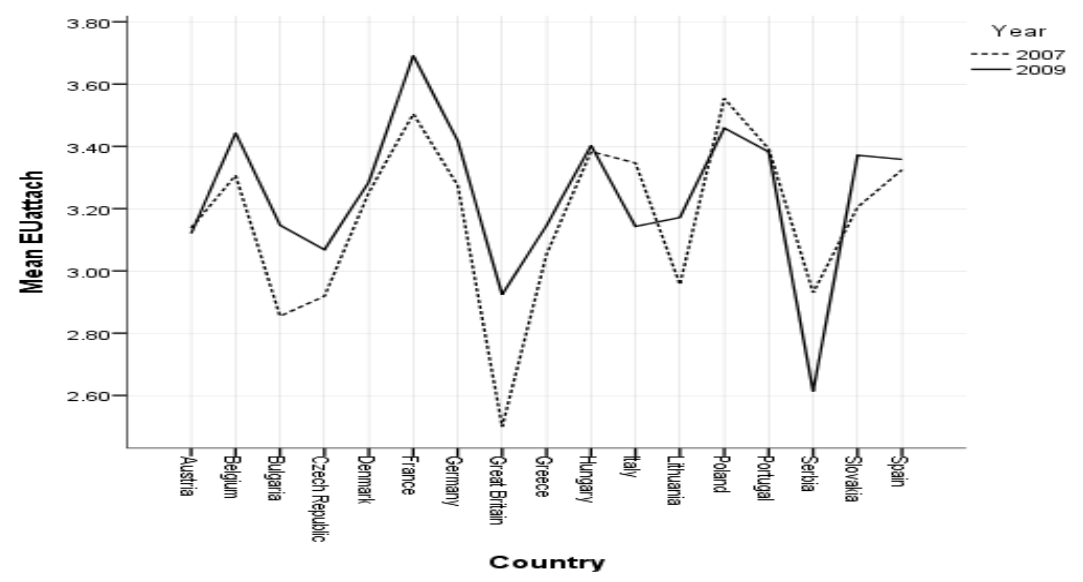

Another indicator from the same survey - the composite index of trust in European institutions (the European Parliament, the European Commission, and the European Council of Ministers) - also displays a drop in EU support among Serbian political elites: from an average of 14.13 in 2007 to 13.50 in 2009 on a scale of 0-30. As in the case of EU attachment, 2009 data shows that MPs belonging to government parties displayed a higher level of trust in EU institutions (scoring 16.89) compared to MPs belonging to opposition parties (9.91).

Finally, the third phase started roughly when the Serbian progressive party, whose leadership once supported Milošević's anti-EU, nationalist and isolationist policies, won the elections in 2012 on the basis of a dual, pro-EU and also proRussian policy. Changes in the elite positions coincided with Serbia entering the process of negotiation about EU accession, putting the new ruling political elite in an institutional position of implementing the pro-EU policies. In return for its

7 Graph is made on the basis of the IntUne elite sample data. 
cooperation with EU institutions on the processes of regional reconciliation and peaceful negotiations on the status of Kosovo, the new Serbian elite enjoyed EU support (in addition to this, it must be noted that the constant latent presence of the Russian influence in Serbian politics puts additional pressure on European institutions to give support to the government's pro-EU policies, regardless of the fact that periodical violations of electoral procedures were recorded in the past several years). Furthermore, even though unmet expectations about Serbia's fast access to EU, ${ }^{8}$ alongside the internal EU crisis, brought about a decline in support for Serbia joining the EU among the general population, ${ }^{9}$ pro-European attitudes still dominate anti-EU narratives in public discourse. Accordingly, Serbia is faced with a situation in which both the ruling elites and most of the opposition parties nominally support the processes of EU integration, but without the necessary agreement about the character of the process (strict adherence to democratic procedures versus their circumvention) and about actors that are recognized as legitimate representatives of pro-EU policies. The fragmented nature of the elite is thus being sustained, delaying the process of the formation of consensual democracy and a corresponding type of elite.

\section{CHANGES IN RECRUITMENT PATTERNS OF THE POLITICAL ELITE 1989-2015}

The following analyses are based on findings of three pieces of empirical research into the political elite (carried out within wider studies into stratification changes). These were undertaken at three key points during systemic changes: in the 'zero' year, 1989, at the very end of the socialist order; then at a time when until then a formal pluralist political order was starting to function essentially in line with established normative principles (2003); and at the present time (2015) when the effects of this activity could be seen in the consolidation of the political elite (in wider terms as a social stratum and, more narrowly, in terms of the definition of the nature of intra-elite relations as consensual or fragmented).

Bearing in mind the existence of texts which have already addressed these pieces of research (see Lazic, 2015), only the basic data about the most recent effort in 2015 will be given here. The sample comprised 192 representatives

8 Serbia received the status of candidate country for EU accession only in 2012, while negotiations about the accession started in 2014.

9 According to data from the Ministry of European Integration of the Government of Republic of Serbia, in $2009,73 \%$ of the population supported Serbia's EU accession; in June 2016 this number had dropped to 41\%, and in June 2017 stabilized at 49\% (source: http://www.seio.gov.rs/upload/ documents/nacionalna_dokumenta/istrazivanja_javnog_mnjenja/javno_mnjenje_jun_17.pdf). 
of the political elite: members of the Parliament (32.8\% of respondents), Government (13.0\%), Constitutional and Supreme Courts (4.7\%), the Parliament and Government of the Autonomous Province of Vojvodina (13.5\%), city authorities in four big cities (Belgrade, Novi Sad, Niš and Kragujevac - 15.1\%) and leaderships of parliamentary political parties (20.8\%). In terms of the rank within the hierarchy, $23.4 \%$ of political elite members that entered our sample were ranked high, $55.2 \%$ were occupying mid-rank positions, while $21.4 \%$ represented low-ranked elite members. In our analysis systematic comparison of the two categories has been made - high-ranked political elite members versus the category comprising mid-ranked and low-ranked elite members. ${ }^{10}$

\section{CHANGES IN THE INTERGENERATIONAL MOBILITY OF POLITICAL ELITE MEMBERS}

Before starting the analysis of empirical findings of changes in the vertical mobility of the political elite in Serbia in the 1989-2015 period, one should be cognizant of the data about the time of their recruitment to the elite, bearing in mind not only the twenty-five-year span but also a number of important social changes which influenced the elite's composition. In the first place, the political elite after 1990 saw the ascendance to its ranks (albeit in very moderate numbers) of individuals from opposition parties, recruited according to principles different from those applied to the cadre of the former nomenklatura (appointed to the elite). The breakthrough of new members, whose ascent rested on political competition, accelerated after the opposition's success at local elections in 1996, and gained particular momentum after the breakdown of Milošević's regime in 2000. This breakdown, as already mentioned, led to a situation whereby the recruitment of new elite members from then on developed completely on the basis of new rules stemming from pluralist political competition, which also entailed new recruitment patterns. And finally, after the 2012 elections and the rise to power of the SNS-SPS coalition, a substantial change took place in the composition of the political elite on both state and perhaps even more local levels, which may again have influenced the characteristics of this group. For this reason we first present data showing who, in view of the mode of recruitment, actually comprised the political elite after the two above-mentioned crucial points: the 2000 and 2012 elections (Table 1).

10 Statistically significant differences between those two groups were found only concerning the period in which they first came to elite positions and their class origin. These differences will be further addressed in the text. 
Table 1 Period in which political elite members took up first political position (2003 and 2015) (\%)

\begin{tabular}{|c|c|c|}
\hline Period of taking up first position & $\mathbf{2 0 0 3}$ & $\mathbf{2 0 1 5}$ \\
\hline Until 1990 & 48.1 & 8.3 \\
\hline $1991-2000$ & 25.7 & 22.4 \\
\hline After 2000 & 26.2 & 69.3 \\
\hline
\end{tabular}

It turns out that, after the political changes of 2000, close to half of this group were former nomenklatura members, who are still found in the current elite, although only marginally. In other words, any interpretation of 2003 survey data should bear in mind that they are largely marked by the principles of the nomenklatura reproduction prevailing in socialism, but that these principles no longer apply according to the most recent findings. As for the latter data, it is important that their interpretation heeds the fact that over two-thirds of current political elite members rose to their positions at a time when the liberal rules of political competition were already largely being applied, which means that the new data indicate the effects of the recruitment principles of this group characteristic of the pluralist political order. In other words, the large majority of the current political elite in Serbia have been recruited according to patterns typical of this order, and may therefore be considered truly new (not only in terms of the personnel heritage of socialism, but primarily in terms of the change in rules of system reproduction).

However, further analysis of the 2015 data reveals differences between highly ranked and mid - and low-ranked elite members in terms of the period when they were first recruited to elite positions. Namely, $15.6 \%$ of those occupying the highest positions were recruited before 1990s, during the socialist regime, comparing to $6.1 \%$ of those occupying mid - and low-ranked positions. Furthermore, while the pattern recorded for the whole sample, indicating that majority of the elite members rose to their positions after the year 2000 -during the period of the pluralist political order, was also characteristic of those occupying mid - and low-rank positions, the same could not be said for those at top positions: $42.2 \%$ of them were first recruited during the 1990s period, and the same percentage of respondents from this group first came to their position after the year 2000. In other words, the higher the position within the hierarchy, the longer is the period the respondent spent at elite positions. Although the majority of the elite members (mostly those occupying lower positions within the hierarchy) entered this group during the period of consolidation of political pluralism through competition of their parties at the parliamentary or local elections, the ascendance to power positions of those occupying top ranks is diversified and includes appointment from above (during the socialist period), electoral success of their parties in situation of limited political pluralism (during the 1990s) as well as competition at relatively fair elections (after the year 2000). These results, however, 
should not be surprising if we have in mind the fact that among those at the top elite positions $17.8 \%$ of respondents were older than 65 years compared to $4.8 \%$ of those at mid - and low-ranked positions. ${ }^{11}$

Focusing now on the narrower subject of the research, we recall that vertical social mobility represents the external 'personnel' expression of the mode of reproduction of the ruling social relations (see Lazić 1987: 9-14). Therefore, the abolishment of the command form of social production, along with the discarding of the appointments principle of nomenklatura recruitment and its replacement with political competition as the mode of obtaining elite political positions, imposes the following assumption: the breakdown of socialism was followed by important changes in the patterns of intergenerational mobility of members of the political elite stratum. The direction of changes was already indicated at the later stage of the socialist order when the until-then pronounced intergenerational openness of this social group to descendants of members of all social groups started to narrow down to descendants of middle-strata members. Research data, however, reveal that the legitimacy-required recruitment of a certain number of descendants of lower social classes/strata members (primarily manual workers) still played a certain role in the appointment process. The abandonment of old legitimacy patterns, growth of economic inequalities (which reduced the opportunity of lower strata descendants to acquire a higher degree of education) and further development of the need for the professionalization of politics (due to an increase in social complexity) support the following hypothesis: the trend to a reduction in the intergenerational recruitment basis of the political elite in relation to lower classes/strata, and the opening towards classes/strata higher in the social hierarchy continues to gain strength. Research data show that this hypothesis is essentially justified (Table 2).

Table 2 Workplace of fathers of members of the political elite (1989, 2003 and 2015) (\%)

\begin{tabular}{|c|c|c|c|}
\hline Social class/stratum $^{*}$ & 1989 & 2003 & 2015 \\
\hline Ruling class/strata & 2,0 & 27,5 & 18,8 \\
\hline Middle class/strata & 21,0 & 38,2 & 44,0 \\
\hline Intermediate stratum & 14,0 & 12,7 & 13,6 \\
\hline Working class/strata & 32,0 & 14,2 & 20,4 \\
\hline Farmers & 31,0 & 7,4 & 3,1 \\
\hline
\end{tabular}

* Social classes/strata: 1. Ruling class: political and economic elite; 2. Middle class: professionals, medium level lower managers, self-employed with higher professional qualifications, medium and small entrepreneurs; 3. Intermediate stratum: clerks with intermediate education, technicians, self-employed with intermediate education; 4. Working class: skilled and non-skilled workers, routine clerks with lower education; 5. Small farmers.

11 The results also show significant differences in the average age of the respondents belonging to the two hierarchical sub-groups within our sample: namely, mean age for those occupying the top ranked positions was 52, while for those at the middle and low positions was 48 . 
An initial look only at findings for the starting (1989) and end year (2015) reveals remarkably large changes in the recruitment patterns of political elites, developing in the predicted direction. The largest nominal change occurred at the very bottom of the social hierarchy: the possibility that a descendant of a farmer would reach a political position declined from highly likely to incidental (a tenfold reduction). Here, however, we must bear in mind that the share of farmers in the overall population in that period more than halved (to $12.8 \%$ according to the 2011 census), so that the decrease in the chance of ascent of this group is less than it may appear at first sight (although it is still four times less than would be proportional). A substantially smaller and yet noticeable decrease also occurred in the recruitment of manual workers' descendants to the political elite: the chance of ascent from the group which represented the largest recruitment pool of the political elite (in absolute rather than relative terms) was reduced two to three times compared to what would be proportional. The opposite tendency is for a dramatic increase in the chance of descendants of the ruling strata members assuming positions within the political elite (up to nine times), while medium-class positions became the most important pool (now also in absolute terms) for the intergenerational replenishment of these positions, with a chance of ascent almost three times larger than would be proportional.

In brief, one may conclude that the assumption concerning the change in the key patterns of reproduction of the political elite was overly moderate: the trend to closure towards the lower social classes/strata was not only sustained, but it was also dramatically accelerated (these strata, with two-thirds participation in the overall recruitment pool, were reduced to less than a quarter). The possibility for the self-reproduction of strata within the ruling class reached unexpectedly large proportions (six to seven times larger than proportional; in the case of the economic elite, intergenerational class transmission of positions in 2012 occurred with $29.3 \%$ of respondents and was thus only barely over that registered for the political elite - see Lazić, in Lazić ed. 2014: 74). It turns out, in brief, that the orientation of descendants of the ruling social group - those with access to the resources (economic and organizational) needed to assume political positions - became so large that it, to a degree, limited the possibility for ascent of descendants of the middle strata (who still, in absolute terms, became the largest recruitment pool for this elite). The fact that elite political positions represent the highest degree of aspiration even for the members/descendants of the economic (as well as cultural) elite is, however, no novelty in Serbian history: it is a constant which may be traced back to the nineteenth century and the establishment of state independence (see Lazić 2011: 99-126).

It must, however, also be noted that the identified changes were not linear, as indicated by the 2003 data. These data should primarily be analyzed in the light 
of the major breakthrough into the political elite of new members about two or three years ago, as a result of the dismantling of Milošević's regime and the massive taking up of positions in state apparatuses by members of until-then opposition parties, many of whom had not belonged to the political elite earlier (lower party cadre, newly-recruited 'sympathizers' seeking positions, etc.). Even at first sight, it is obvious that the basic tendencies registered in the latest research (2015) were manifest some ten years ago, and moreover, in a more pronounced form. Self-reproduction at the top of the hierarchy substantially increased, accompanied by a proportional decrease in the chances of descendants of lower classes/strata members, especially in the case of farmers, in line with the fading of ideological mobilization reliant on traditionalist values. The middle strata became the main intergenerational pool of the political elite, but only in absolute terms, rather than in terms of chance (which in their ranks exceeded what would be proportional by 2-3 times), compared with as much as a ten-fold increase in the case of higher strata.

The remaining explanation connected to changes over the past fifteen or so years has to do with the decreasing participation of ruling strata descendants in the political elite in the 2003-2015 period (with a proportional increase in the share of descendants of middle strata members). Understanding this phenomenon is not difficult: the most recent research was preceded by a new and major change in the composition of the political elite as a result of the SNS victory at the 2012 elections. Since this populist party had (and still has) its foothold primarily in the lower social strata (as with the SRS, away from which it splintered; see Slavujević 2005, 2007; Stojiljković 2015), it is clear that the numerous activists who then took lower and middle elite positions somewhat more often included individuals of hierarchically lower social origin (especially workers). Actually, we can claim that, in view of the important change in the composition of the political elite, after the twelve-year rule of parties which primarily represented the urban (higher and middle) strata of the Serbian population, the research finding of a relatively limited breakthrough of descendants of the lower strata into the elite (manual workers and, minimally, members of intermediate strata, with a continued decrease in farmers' participation) and a further increase in the share of descendants of the middle strata, convincingly confirm the trend to an increasingly strong decline of the chances of the intergenerational ascent of members of the lower social strata to the political (as well as economic) elite.

Finally, it should also be noted that the latest (2015) data show statistically significant differences between highly ranked elite members and those occupying middle and lower elite positions in terms of their class origin. ${ }^{12}$ Namely, the overall

12 Chi-square was $13.737(\mathrm{p}=0.008)$, while Cramer's V was $0.268(0.008)$. 
class origin of the top ranked respondents was lower than of those occupying mid - and low-ranked positions: while almost one half (46.9\%) of the respondents from the latter group represented descendants of the fathers belonging to the middle class, the share of top power positioned respondents with the middle class family origin was significantly lower (34.1\%). At the same time, $11.4 \%$ of them were descendants of the farmers, compared to only $0.7 \%$ of those at middle and lower positions. Since most of the respondents at the top ranked elite positions were those belonging to the ruling coalition, previously stated conclusions about the significant changes in the social composition of the ruling elite after the 2012 elections can also be applied to the analysis of social origin of the two subgroups within the elite.

\section{CHANGES IN THE INTRAGENERATIONAL MOBILITY OF POLITICAL ELITE MEMBERS}

Essentially, trends in intragenerational mobility follow the processes of intergenerational mobility, although changes of positions are in this case, as a rule, less pronounced. Namely, the current social positions of members of social groups are predominantly conditioned by the positions they held at the beginning of their careers. Naturally, an important exception to this rule was the nomenklatura in socialism. In view of the remarkable openness of the group and the appointment as a mode of recruitment of new members, it was in principle entered from lower positions (and in the later stage of the socialist order, usually those held by members of the middle strata: professionals and lower managers). This means that the reproduction of the nomenklatura implied initial upward intragenerational mobility. Furthermore, as indicated above, systemic changes during the 1990s created variability in the composition of the higher social strata, both members of economic and political elites, who were to a substantial degree recruited intragenerationally from the middle strata. Research data show the following changes in intragenerational mobility of the political elite (Table 3).

Table 3 Status of first workplace of political elite members (1989, 2003 and 2015) (\%)

\begin{tabular}{|c|c|c|c|}
\hline Social class/stratum $^{*}$ & 1989 & 2003 & 2015 \\
\hline Ruling class/strata & 8,8 & 11,7 & 8,9 \\
\hline Middle class/strata & 63,4 & 81,6 & 78,6 \\
\hline Intermediate stratum & 17,6 & 4,9 & 9,4 \\
\hline Working class/strata & 10,2 & 1,9 & 3,1 \\
\hline Farmers & $/$ & $/$ & $/$ \\
\hline
\end{tabular}

"Social classes/strata as in Table 2. 
If we first take a look at the polar values (for 1989 and 2015) registering mobility patterns in the final stage of socialism and the period of stabilization of capitalist social relations (as illustrated in Table 3), it predictably transpires that the trends of intragenerational mobility are similar to those for intergenerational mobility, only somewhat less pronounced. A relatively small number of nomenklatura members started their careers in positions of the ruling hierarchy, and the same applies to members of the present day political elite. At the other end of the hierarchical social ladder, the initial position of a farmer in socialism made it impossible for them to reach the top of the social hierarchy, and so it has remained to this day. Furthermore, the legitimacy requirement of recruiting into the nomenklatura, albeit in marginal numbers, individuals from the working class, characteristic of late socialism, has been drastically reduced in the new social situation, while in stabilized capitalism ascent to the political elite also becomes decreasingly accessible to individuals from the intermediate strata. In sum, positions within the middle strata (professional and lower managerial) which in socialism represented by far the most frequent starting point for ascent to the nomenklatura (in absolute as well as relative terms: 4-5 times more frequent than is proportional), during the building of the plural political system became an even stronger condition for ascent to the political elite. In other words, the initial possession of a certain quantity of accumulated resources (cultural, economic or organizational), previously secured through one's family class position, became the necessary precondition for ascent to this stratum of the ruling class (almost identical in the case of the economic elite - see Lazić in Lazić ed. 2014: 171).

Data for the first period of delayed (1990-2000) and then accelerated systemic changes (2000 onwards) do not substantially depart from the described trends. The largest difference may be noted with the sudden leap in the number of political elite members who started their careers in positions within the middle strata. This is due to the fact that the founders and leaders of new political parties, a certain number of whom entered the political elite after the first (and subsequent) parliamentary elections, included a disproportionally large number of intellectuals. This leap was clearly almost completely achieved at the expense of the opportunities of working strata members to make a career ascent to the political elite. This trend was a little mitigated in the latest period due to the breakthrough of numerous SNS cadre to the political elite after the 2012 elections, because, as previously noted, membership of this party shows a somewhat larger presence of individuals of hierarchically lower social strata (from both an inter - and intra-generational point of view). This change, however, is of marginal importance and has not altered the general trend at all: ascent to the political elite, within the frameworks of the liberal-democratic 
political order, as a rule, requires a career start at least half-way up the social hierarchy ladder.

The above conclusions about intragenerational mobility are additionally confirmed by the data about the positions held by political elite members immediately before their recruitment to this stratum. Namely, it may be assumed that under conditions whereby access to the political elite is increasingly limited to members of the middle strata, in socialism as well as in capitalism individuals of lower social origin who seek to climb to the top of the social hierarchy will have to gradually advance in their careers: from a hierarchically lower through a middle to a higher position. To make the analysis simple, research findings will here be presented only for the periods of late socialism (1989) and stabilized capitalist order in Serbia (2015) during which the basic systemic trends were crystallized (Table 4).

Table 4 Social position prior to entry into political elite (1989 and 2015) (\%)

\begin{tabular}{|c|c|c|}
\hline Social class/stratum $^{*}$ & 1989 & 2015 \\
\hline Economic elite & 5,7 & 9,4 \\
\hline Political elite from the start & 8,0 & 4,7 \\
\hline Middle class/strata & 75,9 & 82,3 \\
\hline Intermediate class & 6,1 & 3,6 \\
\hline Working class/strata & 4,2 & $/$ \\
\hline Farmers & $/$ & $/$ \\
\hline
\end{tabular}

"Social classes/strata as in Table 2.

These data indicate that, at the time of socialism, the legitimacy requirement enabled a small number of working class members to be directly appointed to positions in the nomenklatura (meaning that a large number of them - cf. Table 3 - gradually advanced in their careers through middle-class positions). This opportunity completely disappeared during the process of stabilization of the liberaldemocratic political order, wherein direct ascent from hierarchically lower strata/ classes to the political elite was excluded, and even the chances of intermediate strata members making this ascent became very small. On the other hand, although both principles of political elite reproduction - appointment and political competition place the middle strata foremost in their recruitment plans, they still display some differences. Namely, political competition decreases the chance of starting a career in the political elite, which is logical, because competition here begins within the parties themselves as a struggle for higher positions in party hierarchy, which only if successful offers the possibility for ascent to elite position in state apparatuses (assuming that the party concerned wins electoral control over these apparatuses, or at least the right to participate in distribution of positions therein). Under socialism, 
by contrast, appointments from above could (although less frequently as time passed) 'skip' a few rungs of the social hierarchy.

The data, however, show the greater chances of members of economic elite in the pluralist order to transfer to positions of the political elite. While discussion of the issue of the resources which make this career path possible is here pointless, it is still interesting to look at the motives for choosing this particular path. In the briefest terms, to all appearances we still see at work the historical constant of Serbian society, whereby the state is positioned (structurally as well as in the consciousness of the population) as the center of overall social life, ensuring access not only to organizational resources but also to economic ones, and even - not least importantly - to social reputation, which by far exceeds the prestige enjoyed by the economic elite (for more see Lazić 2011).

\section{Family transmission of positions of political elite members}

Crystallization of class social division during the consolidation of the capitalist order in Serbia in the sphere of social mobility may be monitored in yet another way: through 'transmission' of elite positions to one's family members. Namely, although the empirical research of vertical social mobility rests on the analysis of change (or stability) of positions of individuals, it hinges on the implicit assumption of family-based class positions..$^{13}$ While this claim is easy to prove in the sphere of economic positions (since the basic living conditions of nuclear family members are in principle equal), this regularity is revealed only as a trend where mobility is concerned. The working careers of individual members may take different paths and often do - especially at certain life stages (e.g. descendants of economic elite members in developed capitalism often start their careers in professional positions, learning over years to manage a firm: Maclean - Harvey - Press 2006). Still, these differences are often small-scale: barriers dividing classes are as a rule penetrable only for members of the hierarchically closest groupings, all the more so in the case of families, because intraclass homogeneity is a condition for the successful protection and promotion of class interests. The trends with nuclear family members who occupy the same or hierarchically close (work) positions will here be analyzed on the basis of data about the positions of the descendants of elite members in the period of late socialism and during the consolidation of capitalism in Serbia.

13 This assumption, among other things, implies that the positions of members of at least the nuclear family are determined by the highest position occupied by one of its members (the 'dominance approach' - Erikson - Goldthorpe 1992). 
In view of the above statements, it is clear that in the socialist order the possibility of the 'takeover' of elite positions by descendants was in principle excluded. In the liberal-democratic order, on the other hand, there are numerous examples of families 'traditionally' oriented to political careers (the Kennedy, Bush, and Clinton families in the US, or Le Pen in France, etc.), in the absence of a mechanism to limit such an orientation, while the advantages of familyaccumulated resources - economic, organizational, social/networking, etc. - are obvious in a political context. It is clear that the brief recent history of political pluralism in Serbia for the time being excludes such a 'tradition' (although comparable examples have already emerged in the family of the former president of the Republic), while the data relating to descendants who started individual careers and occupy appropriate workplaces are the following (Table 5):

Table 5 Social positions of descendants of political elite members (oldest daughter or son) $(1989,2003$ and 2015) (\%)

\begin{tabular}{|c|c|c|c|}
\hline Social class/stratum $^{*}$ & 1989 & 2003 & 2015 \\
\hline Ruling class/strata & $/$ & 7.3 & 3.8 \\
\hline Middle class/strata & 67.7 & 78.0 & 86.8 \\
\hline Intermediate class & 12.9 & 12.2 & 7.5 \\
\hline Working class/strata & 19.4 & 2.4 & 1.9 \\
\hline Farmers & $/$ & $/$ & $/$ \\
\hline
\end{tabular}

* Social classes/strata as in Table 2.

Although in this case the drawing of conclusions on the basis of the empirical data requires particular caution due to the relatively small numbers of respondents with grown up descendants, trends are clearly noticeable. First, in the late stage of socialism, as already demonstrated, transfer of positions in the nomenklatura to the next generation was in principle precluded (or at least very difficult). Moreover, just as ascent to the ruling group was possible, in a limited scope, to members of hierarchically lower classes/strata, so were the descendants of its members faced with the real possibility of falling into the lower classes/strata (even a third of them!) with the exception of 'segregated' farmers.

The capitalist, liberal-democratic transformation brought about noticeable changes in the career paths of the descendants of political elite members. The more substantial breakthrough of new elite members following the dismantling of Milošević's regime increased the chance that individuals originating from the ruling strata would climb into positions in political or economic elites (in all likelihood, due to the above-mentioned use of family-accumulated resources). 
True, this phenomenon was somewhat mitigated in the most recent period, probably because the new and large-scale change of political elite composition after 2012 ushered in some members originating from lower social class/strata.

While a more detailed and precise elaboration of the issue of the family reproduction of elite positions will have to be left for subsequent research efforts, the data gathered so far clearly confirm the widening gap between the higher and middle classes/strata, on the one hand, and the lower classes/strata on the other. Members of the political elite are increasingly successful in securing their descendants access to the middle strata, from where they may in later stages of their careers rise to elite positions (we should not forget that these descendants are younger people, at the beginning or in the first third of their careers). The opportunity for these descendants to slide into the intermediate strata has been remarkably reduced, while their fall to the class of manual workers has been practically ruled out. Examining this trend against the changes in the intergenerational mobility of current political elite members (Table 2) shows that the process of deepening the gap between the classes/strata who are lower on the hierarchical social level and the middle and higher strata has significantly advanced during the last thirty or so years (from the final stage of the socialist order to the period of the consolidation of capitalist relations and political pluralism).

\section{CONCLUSIONS: TOWARDS THE FORMATION OF A CONSENSUAL TYPE OF POLITICAL ELITE IN SERBIA?}

The conclusions of the above analyses are largely unequivocal. Data about recruitment patterns testify that the change in basic social relations - from socialist to capitalist - substantially altered the recruitment patterns of the ruling class stratum which controls organizational resources. Substitution of the appointment principle, which in socialism was the basis of ascent to this stratum (through political party competition, as well as the legitimacy basis of the social order) has changed both the empirical forms of taking positions in the political elite and its recruitment basis. The most important change involved deepening of the gap between lower social classes and strata, on the one hand, and middle and higher strata, on the other. ${ }^{14}$ This deepening was consequently

14 On the significant growth of economic inequalities in Serbia throughout the course of the process of capitalist consolidation, during which several divisions ("cuts") were established between the economic elite and other classes/strata, between the ruling class and other groups, and between higher and middle strata on the one hand and intermediate and lower on the other - see Manić Mirkov in Lazić ed. 2016. 
reflected in both intergenerational and intragenerational mobility. In socialism, due to its legitimacy requirement, constriction of the recruitment basis of the nomenklatura still left some room for the gradual and even direct ascent of descendants (i.e. members of the strata of manual workers), while stabilization of capitalist relations practically abolished that possibility for both types of mobility (i.e. reduced it to individual cases). Furthermore, while the nomenklatura was in principle both intra - and intergenerationally an open group (true, as a rule, increasingly towards the members of the middle strata), the stratum which controls relatively independent organizational resources (state apparatuses) in capitalism may be intergenerationally and disproportionally self-reproduced, directly using these or other (economic or networking) accumulated resources.

Naturally, in view of the fact that the capitalist order in Serbia has only recently entered the stage of consolidation, the principles of its reproduction including the reproduction of the ruling strata - have not yet taken firm hold, disabling, at the same time, formation of the consensual type of political elite. Thus the research data from the period of blocked transformation (during the last decade of the twentieth century) showed that the recruitment of the political elite still predominantly relied on mobility patterns stemming from the principle of appointment (because the elite itself was only marginally changed in terms of its cadre). The new political regime, established in 2000, brought about a significant change in the composition of this elite and implied more pronounced fluctuation in the patterns of its recruitment: a substantial prevalence of inter - and intragenerational middle class recruitment in the first stage (until 2012), somewhat extended to manual workers and the intermediate strata after the ascent to power of the populist SNS in recent times, but also a clear trend towards self-reproduction in the growth rate of the ruling social group.

To conclude, although political competition became one of the most important mechanisms of ascendance to elite positions, bringing significant changes in recruitment patterns over the socialist period, the increasing rate of the intergenerational self-reproduction of political, as well as economic elites, points to the strong tendency towards their closing to descendants of lower social strata and the growing importance of inherited resources for joining them. In this way, participation in political competition is becoming the privilege of those who possess either cultural capital or economic resources, indicating the gradual formation of a political system that has the characteristics of biased pluralism (see: Connolly, 1969).

Attitudinal changes of political elite members concerning EU accession also testify that the process of post-socialist transformation in Serbia has failed to produce a pluralist political order typical of a consolidated democracy. While the earlier waves of EU enlargement have largely been associated with democratization of the political system and market liberalization in post-socialist countries, it 
seems that in Western Balkan contexts, where EU accession has coincided with an internal crisis of the European Union, the Europeanization process no longer represents a guarantor of stability, growth and democratic consolidation (Agarin, 2017: 2-3). Failed expectations regarding Serbia's relatively fast access to the EU after 'democratic changes', alongside the growing instability of the Union, are giving impetus to EU skepticism, not only among the general population but also among political elites, hardening the process of formation of the 'consensual' elites. In such countries and situations where European institutions and prospects for future access to the Union serve as an external incentive for the further democratization of candidate countries, the EU crisis could potentially undermine the functioning of the liberal-democratic political order.

\section{REFERENCES}

Agarin, Timofey (2017), 'Changes in the Narratives of Europeanization. Reviewing the Impact of the Union before the Crisis', Sudosteuropa Vol. 65, No. 1, pp. 1-9, https://doi.org/10.1515/soeu-2017-0001

Connoly, William (1969), Bias of pluralism, New York, Atherton Press

Erikson, Robert - John Goldthorpe (1992), The Constant Flux, Oxford, Clarendon Press

Goati, Vladimir, ed. (2002), Partijska scena Srbije posle 5. oktobra 2000 (The Party Scene of Serbia after October $5^{\text {th }}$ 2000), Beograd, Friedrich Ebert Stiftung - Institut društvenih nauka

Goati, Vladimir (2006), Partijske borbe u Srbiji u postoktobarskom razdoblju (Party Struggles in Serbia after the 2000 Turnover), Beograd, Friedrich Ebert Stiftung - Institut društvenih nauka

Higley, John - Gyorgy Lengyel, eds. (2000), Elites After State Socialism, Lanham MD, Rowman \& Littlefield

Higley, John - Michael Burton (2006), Elite Foundations of Liberal Democracy, Lanham MD, Rowman \& Littlefield

Jovanović, Milan (1997), Izborni sistemi - Izbori u Srbiji 1990-1996 (Electoral Systems - Elections in Serbia 1990-1996), Beograd, Institut za političke studije - Službeni glasnik

Jovanović, Nataša - Selena Radović - Aleksandra Marković (2016), 'Konsolidacija izborne demokratije, formiranje pluralističke političke elite i njena ideološka orijentacija' ('Democratic consolidation, formation of pluralist political elite and ideological orientations'), in: Lazić, Mladen, ed., Politička elita u Srbiji u periodu konsolidacije kapitalističkog poretka (Political Elite 
in Serbia in the Period of Capitalism Consolidation), Beograd, Institut za sociološka istraživanja - Čigoja štampa

Lazić, Mladen (1987), U susret zatvorenom društvu (Towards the Closed Society), Zagreb, Naprijed

Lazić, Mladen - Vladimir Vuletić (2009), 'The Nation State and the EU in the Perceptions of Political and Economic Elites: The Case of Serbia in Comparative Perspective', Europe-Asia Studies, Vol. 61, No. 6, pp. 987-1001, http://dx.doi.org/10.1080/09668130903063518

Lazić, Mladen (2011), Čekajući kapitalizam (Waiting for Capitalism), Beograd, Službeni glasnik

Lazić, Mladen (2014), 'Regrutacija ekonomske elite: kontinuitet i promene' (Recruitment of economic elites: continuity and change), in: Lazić, Mladen, ed. Ekonomska elita u Srbiji u periodu konsolidacije kapitalističkog poretka (Economic Elite in Serbia during the Period of Capitalism Consolidation. Beograd, Institut za sociološka istraživanja - Čigoja štampa.

Lazić, Mladen (2015), 'Making New Economic Elite in Serbia', Sudosteuropa, Vol. 63, No. 4., pp. 531-548, http://www.ios-regensburg.de/fileadmin/doc/ SOE/SOE_2015_4_Lazic_Intro.pdf

Lutovac, Zoran, ed. (2006), Političke stranke i birači u državama bivše Jugoslavije (Political Parties and Voters in Ex Yugoslav States), Beograd, Friedrich Ebert Stiftung - Institut društvenih nauka.

Manić, Željka - Anđelka Mirkov (2016), 'Materijalni položaj političke elite' ('Material position of political elite'), in: Lazić, Mladen ed., Politička elita u Srbiji u periodu konsolidacije kapitalistickog poretka (Political Elite in Serbia in the Period of Capitalism Consolidation), Beograd, ISI - Čigoja štampa.

Maclean, Mairi - Charles Harvey - Jon Press (2006), Business Elites and Corporate Governance in France and the UK, Houndmills - Basingstoke, Palgrave Macmillan

Slavujević, Zoran (2005), 'Promena socijalne utemeljenosti i socijalne strukture pristalica relevantnih političkih stranaka u Srbiji prvih godina XXI veka' ('Changes in the social basis and social positions of the relevant political parties supporters in Serbia at the beginning of $21^{\text {st }}$ century'), in: Lutovac, Zoran, ed., Demokratija u političkim strankama Srbije (Democracy and Political Parties in Serbia), Beograd, Institut društvenih nauka - Friedrich Ebert Stiftung

Slavujević, Zoran (2007), Izborne kampanje. Pohod na birače. Slučaj Srbije od 1990. do 2007. godine (Election Campaigns. Stuggles for the Voters. The Case of Serbia 1990-2007), Beograd, Friedrich Ebert Stiftung - Institut društvenih nauka - FPN 
Stojiljković, Zoran (2015), Sva lica opozicije (All Faces of Opposition Parties), Beograd, Vukotić media

Vukomanović, Dijana (2010), Obnova partijskog pluralizma u Srbiji krajem $X X$ veka (Renewal of Party Pluralism in Serbia at the End of 20 th Century), Beograd: Institut za političke studije 
